\title{
The R271W mutant form of Pit-1 does not act as a dominant inhibitor of Pit-1 action to activate the promoters of GH and prolactin genes
}

\author{
Masahiko Kishimoto, Yasuhiko Okimura ${ }^{1}$, Mariko Fumoto, Genzo Iguchi, Keiji Iida, Hidesuke Kaji ${ }^{2}$ and \\ Kazuo Chihara \\ Division of Endocrinology/Metabolism, Neurology and Hematology/Oncology, Department of Clinical Molecular Medicine and \\ ${ }^{1}$ Department of Basic Allied Medicine, Kobe University Graduate School of Medicine and ${ }^{2}$ College of Nursing Art and Culture, Kobe, Japan \\ (Correspondence should be addressed to Y Okimura, Department of Basic Allied Medicine, Kobe University School of Medicine, 7-10-2 Tomogaoka, \\ Suma-ku, Kobe 654-0142, Japan; Email: okimura@ams.kobe-u.ac.jp)
}

\begin{abstract}
Objective: Genetic abnormalities of the pituitary specific transcription factor, Pit-1, have been reported in several patients with GH, prolactin (PRL) and TSH deficiencies. The most common is a mutation altering an arginine to a tryptophan in codon 271 (R271W) in one allele of the Pit- 1 gene. According to the previous in vitro expression study, R271W acted as a dominant negative inhibitor of the wild type to activate the GH promoter. However, healthy carriers with this mutation, who should be affected by the dominant negative effect of R $271 \mathrm{~W}$, have also been reported. The aim of this study was to clarify in more detail the function of this mutant form of Pit-1.

Methods: Transcriptional activity of R271W for the expression of Pit-1-associated genes was investigated in COS7 cells with the aid of transient transfection assays. The $1.8 \mathrm{~kb}$ rat GH, $0.6 \mathrm{~kb}$ rat PRL or $1.9 \mathrm{~kb}$ rat PRL $5^{\prime}$-flanking regions were inserted upstream of the luciferase reporter gene and were used for functional analysis of R271W. Another reporter gene containing seven Pit-1 responsive elements was also used. The same experiments were also performed using JEG3 and CHO cells. Results: We could not confirm the dominant negative effect of R271W on wild type Pit-1. Furthermore, our expression study revealed that $\mathrm{R} 271 \mathrm{~W}$ could activate the promoters of GH and PRL genes to levels similar to the wild type.

Conclusion: Taken together with the evidence that phenotypically normal cases have been reported with this mutation, our results deny the relationship between R271W and combined pituitary hormone deficiency.
\end{abstract}

European Journal of Endocrinology 148 619-625

\section{Introduction}

Pit-1 is a pituitary-specific transcription factor required for development of the three pituitary cell types, somatotrophs, lactotrophs and thyrotrophs, as well as the expression of growth hormone $(\mathrm{GH})$, prolactin (PRL), GH-releasing hormone receptor, thyrotropin- $\beta$ subunit (TSH- $\beta$ ) and Pit-1 genes (1-8). Therefore, abnormalities of the Pit-1 gene lead to GH, PRL and TSH deficiencies. To date, several mutations of the human Pit-1 gene have been reported in patients with combined pituitary hormone deficiencies (CPHDs) (9-31). Analysis of the pedigrees of these patients and the in vitro expression studies revealed that some mutations in the Pit-1 gene (G172X, E250X, A158P, R143Q, $\mathrm{P} 239 \mathrm{~S})$ lead to a recessive phenotype (23-27), while another mutant, R271W, leads to a dominant negative phenotype (9-19).

In this present study, to clarify the precise mechanism by which R271W dominantly inhibits wild type Pit-1 to activate the targeted genes, we evaluated the transcriptional activity of R271W. However, surprisingly, in contrast to a previous report that this mutant acted as a dominant inhibitor of wild type Pit-1 to activate the promoter of $\mathrm{GH}$ gene (9), R271W did not inhibit the effect of the wild type on the promoter of $\mathrm{GH}$ gene as well as PRL gene, and could activate these promoters to a level similar to wild type Pit-1, at least in our experimental conditions. These results, and the existence of healthy carrier with this mutation (11), suggest that further investigation will be needed to clarify how R271W leads to CPHD. 


\section{Materials and methods}

\section{Materials and cell culture}

Fetal calf serum and Dulbecco's modified Eagle's medium were obtained from Life Technologies, Inc. (Tokyo, Japan). COS7, JEG-3, and CHO cells were maintained in Dulbecco's modified Eagle's medium with 10\% $(\mathrm{v} / \mathrm{v})$ calf serum. All culture media contained penicillin G (100 units/ml) and kanamycin $(100 \mu \mathrm{g} / \mathrm{ml})$.

\section{Construction of wild type and mutant form (R271W) of Pit-1 expression vector}

Human Pit-1 cDNA was inserted into an expression vector (pcDNA3.1.) and this expression vector was named pcDNA3.1-wild type Pit-1. R271W expression vector (named pcDNA3.1-R271W) was constructed with a site-directed mutagenesis kit (Stratagene, La Jolla, CA, USA) according to the manufacturer's instructions. Briefly, Pfu Turbo DNA polymerase was used to react $50 \mathrm{ng}$ template DNA (pcDNA3.1-wild type Pit-1) with mutant sense primer (5'-CAGAGAGAAAAATGGGTGAAAAC- $\left.3^{\prime}\right)$ and mutant anti-sense primer $\left(5^{\prime}\right.$-GTTTTCACCCATTTTTCTCTCTG- $\left.3^{\prime}\right)$. This reaction involved $30 \mathrm{~s}$ of denaturation at $95^{\circ} \mathrm{C}$ and 15 cycles consisting of $30 \mathrm{~s}$ of denaturation at $95^{\circ} \mathrm{C}$, $1 \mathrm{~min}$ of annealing at $55^{\circ} \mathrm{C}$ and $5 \mathrm{~min}$ of extension at $68^{\circ} \mathrm{C}$. After digesting the non-mutated parental DNA template with DpnI, pcDNA3.1-R271W was successfully transformed. The complete Pit-1 DNA sequence in pcDNA3.1-R271W was determined to exclude the possibility of a second mutation. Another mutant form of Pit-1 (E250X) expression vector (named pcDNA3.1-E250X) was constructed as described previously (29). E250X is a previously reported mutant form of Pit-1 that has completely lost its transcriptional activity because of the defect in the binding activity to DNA (24).

\section{Reporter gene construction and transient expression analysis using luciferase assay}

Of the rat GH promoter $1.8 \mathrm{~kb}$, and $0.6 \mathrm{~kb}$ of the rat PRL promoter, $1.9 \mathrm{~kb}$ of the rat PRL promoter, or multimerized Pit-1 response elements which are derived from the $1 \mathrm{P}$ site of the rat PRL gene, were inserted upstream of the luciferase gene. These reporter constructs were named $1.8 \mathrm{k}$ GH-Luc, $0.6 \mathrm{k}$ PRL-Luc, $1.9 \mathrm{k}$ PRL-Luc and $1 \mathrm{P}-\mathrm{Luc}$, respectively. These plasmids were introduced into COS7, JEG-3 or CHO cells using LipofectAce (Invitrogen, Tokyo, Japan). First, $2 \mu \mathrm{g} 1.8 \mathrm{k}$ GH-Luc or $0.6 \mathrm{k}$ PRL-Luc were transfected into COS7 cells in $35 \mathrm{~mm}$ dishes with (i) $0.6 \mu \mathrm{g}$ pcDNA3.1., (ii) $0.3 \mu \mathrm{g}$ pcDNA3.1. and $0.3 \mu \mathrm{g}$ pcDNA3.1-wild type Pit-1, (iii) $0.3 \mu \mathrm{g}$ pcDNA3.1. and $0.3 \mu \mathrm{g}$ pcDNA3.1-R271W, or (iv) $0.3 \mu \mathrm{g}$ pcDNA3.1-wild type Pit-1 and $0.3 \mu \mathrm{g}$ pcDNA3.1-R271W to evaluate the basal transcriptional activity and dominant negative effect of R271W. Because a longer promoter of the PRL gene $(1.0 \mathrm{~kb})$ was used in the previous report (9), the same functional analysis of R271W was done using $1.9 \mathrm{k}$ PRL-Luc. 1P-Luc was also used instead of $1.8 \mathrm{k}$ GH-Luc, $0.6 \mathrm{k}$ PRL-Luc and $1.9 \mathrm{k}$ PRL-Luc.

To exclude the possibility that the results were cellspecific phenomena, functional analysis using JEG-3 cells and CHO cells was also performed. Two micrograms of $0.6 \mathrm{k}$ PRL-Luc were transfected into JEG-3 cells or $\mathrm{CHO}$ cells in $35 \mathrm{~mm}$ dishes with (i) $0.6 \mu \mathrm{g}$ pcDNA3.1., (ii) $0.3 \mu \mathrm{g}$ pcDNA3.1. and $0.3 \mu \mathrm{g}$ pcDNA3.1-wild type Pit-1, (iii) $0.3 \mu \mathrm{g}$ pcDNA3.1. and $0.3 \mu \mathrm{g}$ pcDNA3.1-R271W, or (iv) $0.3 \mu \mathrm{g}$ pcDNA3.1wild type Pit-1 and $0.3 \mu \mathrm{g}$ pcDNA3.1-R271W.

Furthermore, we also used the lower dose of Pit-1 expression vectors because $0.3 \mu \mathrm{g}$ Pit- 1 expression vectors seemed to be the saturating dose to activate $0.6 \mathrm{k}$ PRL-Luc and 1P-Luc in COS7 cells. Two micrograms of $0.6 \mathrm{k}$ PRL-Luc or 1P-Luc were transfected into COS7 cells in $35 \mathrm{~mm}$ dishes with (i) $0.2 \mu \mathrm{g}$ pcDNA3.1., (ii) $0.1 \mu \mathrm{g}$ pcDNA3.1. and $0.1 \mu \mathrm{g}$ pcDNA3.1-wild type Pit-1, (iii) $0.1 \mu \mathrm{g}$ pcDNA3.1. and $0.1 \mu \mathrm{g}$ pcDNA3.1R271W, (iv) $0.1 \mu \mathrm{g}$ pcDNA3.1. and $0.1 \mu \mathrm{g}$ pcDNA3.1E250X, (v) $0.2 \mu \mathrm{g}$ pcDNA3.1-wild type Pit-1, (vi) $0.1 \mu \mathrm{g}$ pcDNA3.1-wild type Pit-1 and $0.1 \mu \mathrm{g}$ pcDNA3.1-R271W, or (vii) $0.1 \mu \mathrm{g}$ pcDNA3.1-wild type Pit-1 and 0.1 $\mu \mathrm{g}$ pcDNA3.1-E250X. E250X is a previously reported mutant form of Pit-1 that has completely lost its transcriptional activity because of a defect in binding activity to DNA (24). In this experiment, a calcium phosphate transfection kit (Invitrogen) was also used to exclude the possibility that different transfection methods could lead to opposing results to the previous report (9).

Twenty nanograms of pCMV-RL containing the cDNA encoding Renilla luciferase (Promega, Tokyo, Japan) were co-transfected in each transfection to normalize the luciferase activity. In each experiment, cells were harvested $48 \mathrm{~h}$ after the transfection, and luciferase activities were measured with a Turner design luminometer TD-20/20 using the dual luciferase assay system (Promega).

\section{Western blot analysis}

To rule out the possibility that the changes in expression levels could explain the absence of a dominant negative effect of R $271 \mathrm{~W}$ on the wild type, we performed Western blot analysis. Three micrograms of pcDNA3.1-wild type Pit-1 or pcDNA3.1-R271W were introduced into COS7 cells in $100 \mathrm{~mm}$ dishes using LipofectAce. Forty-eight hours after the transfection, proteins were extracted from the cells and immunoprecipitated with anti-Pit-1 antibody (Santa Cruz Biotechnology, Santa Cruz, CA, USA). These samples were run on 14\% SDS-PAGE and anti-Pit-1 antibody was used for Western blotting. 


\section{Analysis of the nuclear translocation ability of R271W using chimera constructs with green fluorescent protein (GFP)}

Wild type Pit-1 or R271W cDNA was inserted in frame into the XhoI-KpnI sites in the multiple cloning sites of pEGFPC3 (Clontech Laboratories, Inc., Palo Alto, CA, USA) and these plasmids were named wild type Pit-1pEGFP and R271W-pEGFP, respectively. One microgram of pEGFPC3, wild type Pit-1-pEGFP or R271W-pEGFP was introduced into COS7 cells in $35 \mathrm{~mm}$ dishes with the aid of LipofectAce according to the manufacturer's instructions. Forty-eight hours after transfection, fluorescent images were examined.

\section{Results}

\section{Mutation from $R$ to W (CGG to TGG) in codon 271 was successfully made}

The complete Pit-1 DNA sequence in pcDNA3.1$\mathrm{R} 271 \mathrm{~W}$ revealed that only one mutation, a $\mathrm{C}$ to $\mathrm{T}$ mutation in codon 271 (Fig. 1). This mutation leads to the substitution of $\mathrm{W}$ for $\mathrm{R}$ in codon 271 .

\section{R271W does not act as a dominant inhibitor of Pit-1 action to activate $1.8 \mathrm{k}$ GH-Luc and 0.6 k PRL-Luc in COS7 cells}

R271W could activate $1.8 \mathrm{k} \mathrm{GH}-\mathrm{Luc}$ (Fig. 2A) and $0.6 \mathrm{k}$ PRL-Luc (Fig. 2B) up to levels similar to wild type Pit-1. Furthermore, when $0.3 \mu \mathrm{g}$ pcDNA3.1-R271W were cotransfected with $0.3 \mu \mathrm{g}$ pcDNA3.1-wild type Pit-1, R271W did not show a dominant negative effect on wild type Pit-1 to activate $1.8 \mathrm{k} \mathrm{GH}$-Luc (Fig. 2A) and $0.6 \mathrm{k}$ PRL-Luc (Fig. 2B).

\section{R271W does not act as a dominant inhibitor of Pit-1 action to activate $1.9 \mathrm{k}$ PRL-Luc and IP-Luc in COS7 cells}

R271W could activate $1.9 \mathrm{k}$ PRL-Luc (Fig. 3A) and 1P-Luc (Fig. 3B) to levels similar to wild type Pit-1. Furthermore, when $0.3 \mu \mathrm{g}$ pcDNA3.1-R271W were co-transfected with $0.3 \mu \mathrm{g}$ pcDNA3.1-wild type Pit-1, R271W showed no dominant negative effect on wild type Pit-1 to activate $1.9 \mathrm{k}$ PRL-Luc (Fig. 3A) and 1P-Luc (Fig. 3B).

\section{R271W does not act as a dominant inhibitor of Pit-1 action to activate 0.6 $k$ PRL-Luc in other Pit-1 deficient cell lines, JEG3 and $\mathrm{CHO}$ cells}

R271W could activate the $0.6 \mathrm{k}$ PRL-Luc to levels similar to wild type Pit-1, and when co-transfected with wild type Pit-1, R271W did not show a dominant

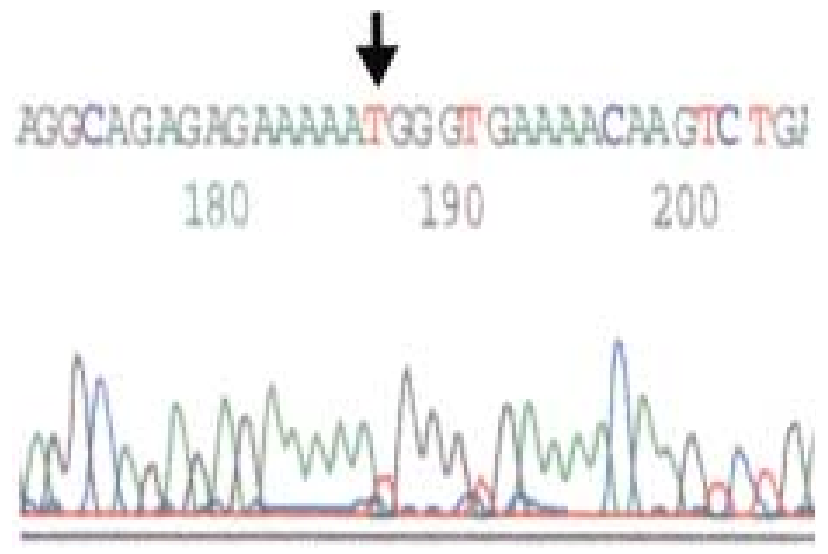

Figure 1 Confirmation of $C$ to $T$ mutation in codon 271 (arrow) in the Pit-1 cDNA inserted into the expression vector by direct sequence.

A. Fold induction

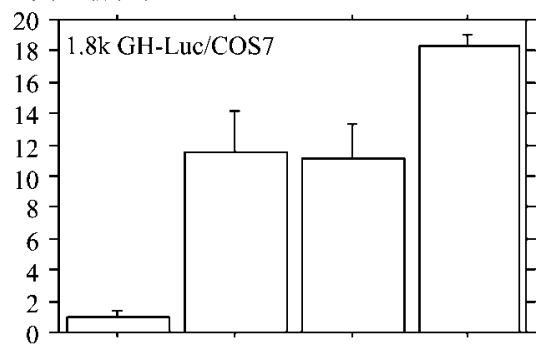

B. Fold induction

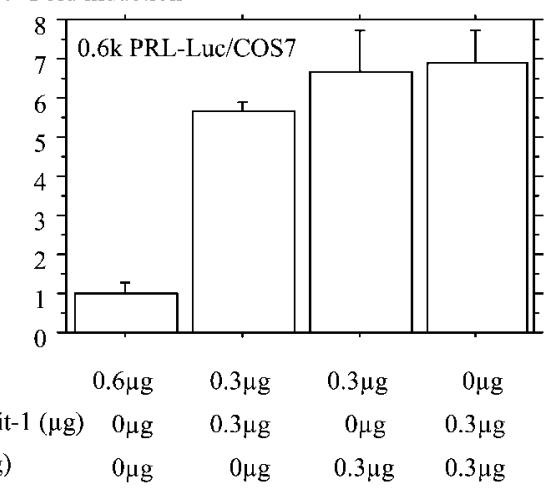

Figure 2 Transfection analysis using COS7 cells showed no dominant negative effect of R271W on wild type Pit-1. Of the rat $\mathrm{GH}$ promoter $1.8 \mathrm{~kb}(\mathrm{~A})$ and $0.6 \mathrm{~kb}$ of the rat $\mathrm{PRL}$ promoter

(B) were inserted upstream of the luciferase gene.

These reporter constructs were named $1.8 \mathrm{k} \mathrm{GH}$-Luc and $0.6 \mathrm{k}$

$\mathrm{PRL}-\mathrm{Luc}$ respectively. Two micrograms of $1.8 \mathrm{k} \mathrm{GH}$-Luc or $0.6 \mathrm{k}$ PRL-Luc were transfected into COS7 cells in $35 \mathrm{~mm}$ dishes with (i) $0.6 \mu \mathrm{g}$ pcDNA3.1., (ii) $0.3 \mu \mathrm{g}$ pcDNA3.1. and $0.3 \mu \mathrm{g}$ pcDNA3.1-wild type Pit-1, (iii) $0.3 \mu \mathrm{g}$ pcDNA3.1. and $0.3 \mu \mathrm{g}$ pcDNA3.1-R271W, or (iv) $0.3 \mu \mathrm{g}$ pcDNA3.1-wild type Pit-1 and $0.3 \mu \mathrm{g}$ pcDNA3.1-R271W. Values are expressed as multiples of induction relative to the basic activity without Pit-1 expression vector and represent the means $\pm S$. E. of at least three determinations. 
A. Fold induction

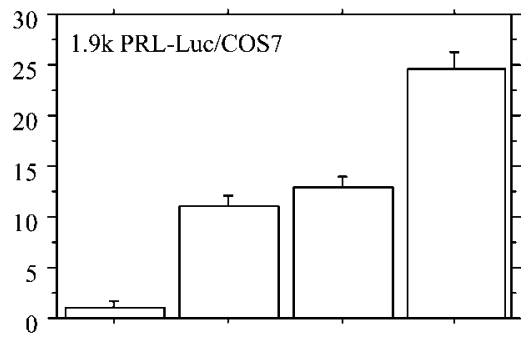

B. Fold induction

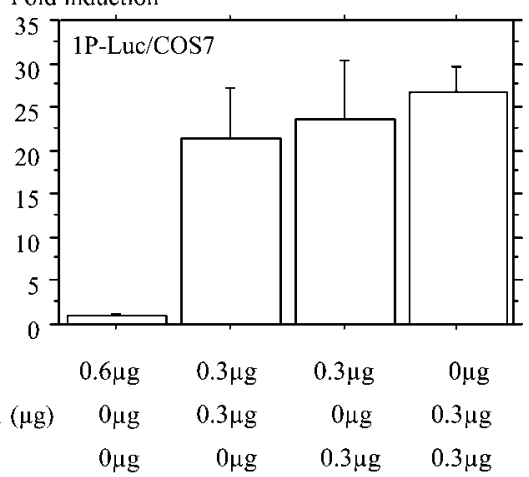

Figure 3 R271W did not show a dominant negative effect even when other reporter constructs were used. Of the rat PRL promoter $1.9 \mathrm{~kb}(\mathrm{~A})$ and multimerized Pit-1 response elements which are derived from the $1 \mathrm{P}$ site of the rat $P R L$ gene $(B)$ were inserted upstream of the luciferase gene. These reporter constructs were named 1.9 k PRL-Luc and 1P-Luc respectively. Two micrograms of $1.9 \mathrm{k}$ PRL-Luc or 1P-Luc were transfected into COS7 cells in $35 \mathrm{~mm}$ dishes with (i) $0.6 \mu \mathrm{g}$ pcDNA3.1., (ii) $0.3 \mu \mathrm{g}$ pcDNA3.1. and $0.3 \mu \mathrm{g}$ pcDNA3.1-wild type Pit-1, (iii) $0.3 \mu \mathrm{g}$ pcDNA3.1. and $0.3 \mu \mathrm{g}$ pcDNA3.1-R271W, or (iv) $0.3 \mu \mathrm{g}$ pcDNA3.1-wild type Pit-1 and $0.3 \mu \mathrm{g}$ pcDNA3.1-R271W. Values are expressed as multiples of induction relative to the basic activity without Pit-1 expression vector and represent the means $\pm \mathrm{S}$.E. of at least three determinations.

negative effect on wild type Pit-1 even in JEG3 cells (Fig. 4A) and CHO cells (Fig. 4B) as well as COS7 cells.

\section{When co-transfected with wild type Pit-1, R271W but not E250X additively activated 0.6 k PRL-Luc and 1P-Luc in COS7 cells}

R271W but not E250X could activate $0.6 \mathrm{k}$ PRL-Luc and 1P-Luc up to levels similar to wild type Pit-1 (Fig. 5A and $\mathrm{B})$. In addition, when co-transfected with wild type Pit-1, R271W additively activated $0.6 \mathrm{k}$ PRL-Luc and 1P-Luc, while E250X did not (Fig. 5A and B).

\section{Transfection analysis using calcium phosphate leads to similar results}

Even when introduced into the COS7 cells using calcium phosphate, R271W but not E250X could activate $1 \mathrm{P}-$-Luc to levels similar to wild type Pit-1, and when co-transfected with wild type Pit-1, R271W but not E250X additively activated 1P-Luc (Fig. 5C).

A. Fold induction

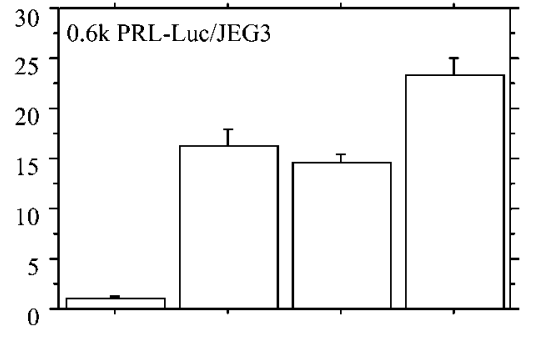

B. Fold induction

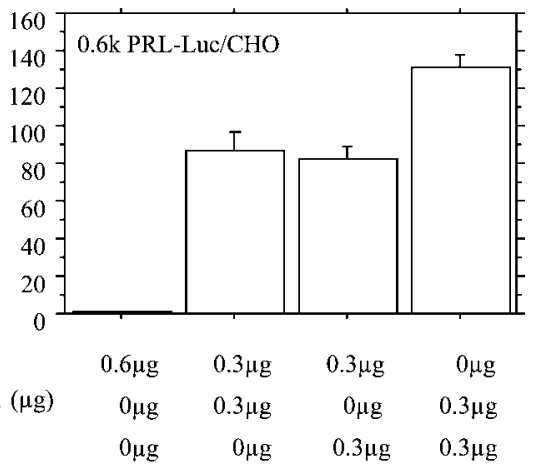

Figure 4 Transfection analysis using other Pit-1 deficient cell lines, JEG3 (A) and CHO cells (B), also showed no dominant negative effect of R271W on wild type Pit-1. Two micrograms of $0.6 \mathrm{k}$ PRL-Luc were transfected into COS7 cells in $35 \mathrm{~mm}$ dishes with (i) $0.6 \mu \mathrm{g}$ pcDNA3.1., (ii) $0.3 \mu \mathrm{g}$ pcDNA3.1. and $0.3 \mu \mathrm{g}$ pcDNA3.1-wild type Pit-1, (iii) $0.3 \mu \mathrm{g}$ pcDNA3.1. and $0.3 \mu \mathrm{g}$ pcDNA3.1-R271W, or (iv) $0.3 \mu \mathrm{g}$ pcDNA3.1-wild type Pit-1 and $0.3 \mu \mathrm{g}$ pcDNA3.1-R271W to evaluate the basal transcriptional activity and dominant negative effect of R271W. Values are expressed as multiples of induction relative to the basic activity without Pit-1 expression vector and represent the means \pm S.E. of at least three determinations.

\section{R271W was expressed and accumulated into the nucleus as wild type Pit-1}

Wild type Pit-1 or R271W was expressed to a similar extent when $3 \mu \mathrm{g}$ pcDNA3.1-wild type Pit-1 or pcDNA3.1-R271W were transfected into the COS7 cells (Fig. 6A). According to the fluorescent images of the expressed fusion proteins, nuclear accumulations of wild type Pit-1-GFP and R271W-GFP were observed in all of the cells analyzed (Fig. 6C and D). Cells transfected with only the GFP expression vector were also analyzed as controls. In the control cells, GFP was distributed homogeneously in both the cytoplasm and the nucleus (Fig. 6B).

\section{Discussion}

Pit-1 has a important role in the somatotrophs, lactotrophs and thyrotrophs. Actually, mutations in this transcription factor are responsible for two types of genetically dwarf mice, that is Snell dwarf and dwarf Jackson mice; both are deficient in GH, PRL and TSH (5). 
A. Fold induction

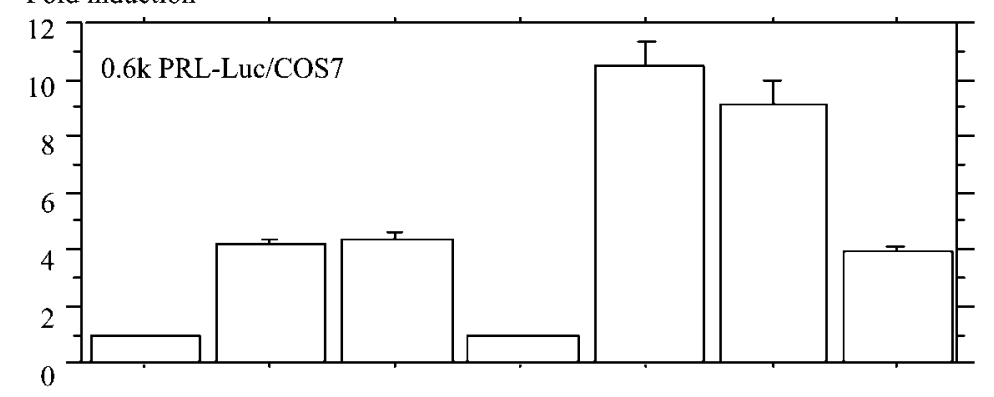

B. Fold induction

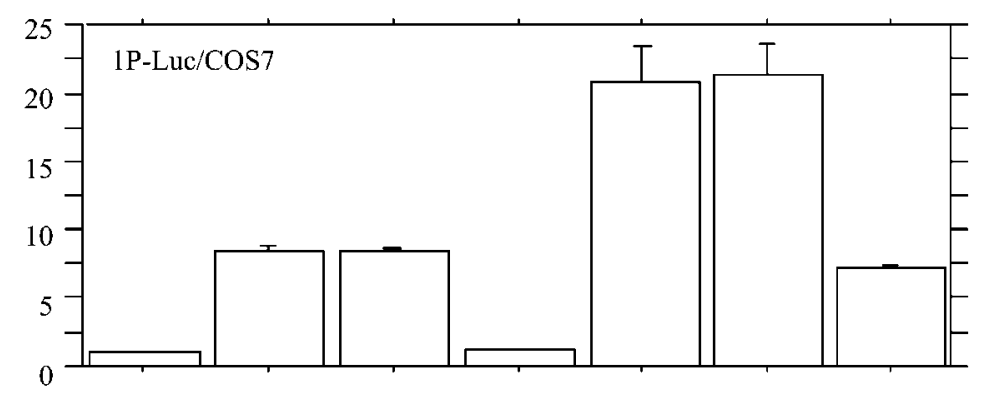

C. Fold induction

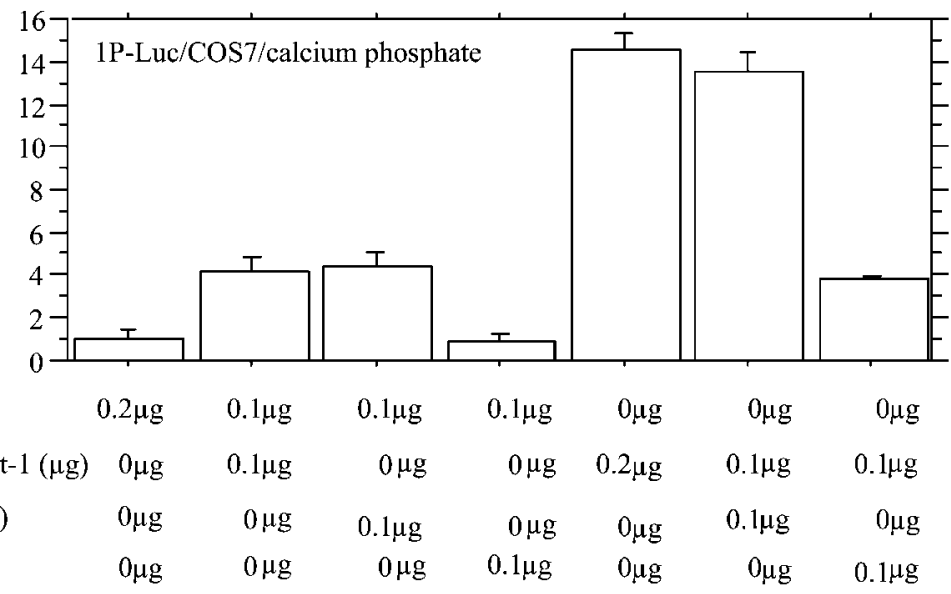

Figure 5 When co-transfected with wild type Pit-1, R271W additively activated 0.6k PRL-Luc and 1P-Luc, while E250X did not. Two micrograms of $0.6 \mathrm{k}$ PRL-Luc or $1 \mathrm{P}$-Luc were transfected into COS7 cells in $35 \mathrm{~mm}$ dishes with (i) $0.2 \mu \mathrm{g}$ pcDNA3.1., (ii) $0.1 \mu \mathrm{g}$ pcDNA3.1. and 0.1 $\mu \mathrm{g}$ pcDNA3.1-wild type Pit-1, (iii) $0.1 \mu \mathrm{g}$ pcDNA3.1. and $0.1 \mu \mathrm{g}$ pcDNA3.1-R271W, (iv) $0.1 \mu \mathrm{g}$ pcDNA3.1. and 0.1 $\mu \mathrm{g}$ pcDNA3.1-E250X, (v) $0.2 \mu \mathrm{g}$ pcDNA3.1-wild type Pit-1, (vi) $0.1 \mu \mathrm{g}$ pcDNA3.1-wild type Pit-1 and $0.1 \mu \mathrm{g}$ pcDNA3.1-R271W, or (vii) $0.1 \mu \mathrm{g}$ pcDNA3.1-wild type Pit-1 and $0.1 \mu \mathrm{g}$ pcDNA3.1-E250X. E250X is a previously reported mutant form of Pit-1 that has completely lost its transcriptional activity because of a defect in binding activity to DNA (24). Transfection was done with the aid of LipofectAce $(A, B)$ or calcium phosphate (C). Values are expressed as multiples of induction relative to the basic activity without Pit-1 expression vector and represent the means \pm S.E. of at least three determinations.

In 1992, Tatsumi et al. (27) reported the first human case of CPHD consisting of GH, PRL and TSH deficiencies due to Pit-1 abnormality. In their case, the proband had a homozygous mutation that converts $\mathrm{R}$ in codon 172, which locates in the POU DNA binding domain, to a termination codon. In the same year, Pfaffle et al. (25) reported two familial cases with CPHD. Mutation from $\mathrm{A}$ to $\mathrm{P}$ in codon 158, and deletion of the Pit-1 gene were detected in their cases.
Also in the same year, Radovick et al. (9) described another CPHD patient with mutation of the Pit-1 gene. In this case, a point mutation which converts $\mathrm{R}$ in codon 271 to $\mathrm{W}$, was identified in one allele. In this report, they performed an in vitro expression study and suggested that, although the patient had only one mutant allele, R271W had a dominant negative effect on wild type Pit-1 to activate the Pit-1 targeted genes, leading to CPHD. Currently, there are at least 26 known 
A.
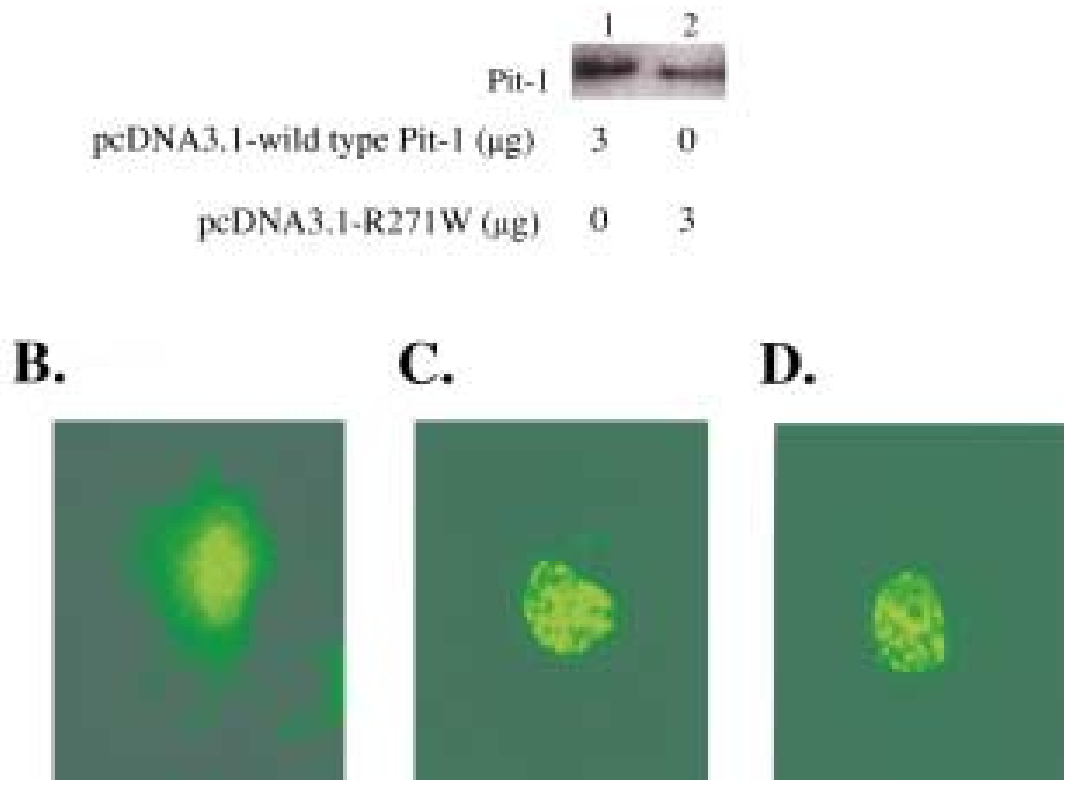

Figure 6 R271W was expressed and accumulated into the nucleus as wild type Pit-1. COS7 cells in $100 \mathrm{~mm}$ dishes were transfected with $3 \mu \mathrm{g}$ pcDNA3.1-wild type Pit-1 or pcDNA3.1-R271W. As described in Materials and methods, anti-Pit-1 antibody was used for Western blotting (A). COS7 cells were transfected with the expression vector containing chimera constructs of GFP with wild type Pit-1 or R271W, and $48 \mathrm{~h}$ after the transfection, their fluorescent images were analyzed. Cells transfected with only the GFP expression vector, as a control, were also analyzed. GFP alone was distributed homogeneously in both the cytoplasm and the nucleus (B). Nuclear accumulation of wild type Pit-1-GFP and R271W-GFP was observed in all the cells analyzed (C, D).

CPHD patients with mutation of the Pit-1 gene. Because among them 12 patients have a heterozygous R271W mutation, R271W was believed to be a common cause of Pit-1 dysfunction (32). Most cases with R271W were sporadic and there were only two familial cases with this mutation. Okamoto et al. (11) reported the first family with $\mathrm{R} 271 \mathrm{~W}$. They described a patient who was heterozygous for this mutation. They also identified the same mutation in an apparently healthy father, grandmother and also aunts who should have been affected by a dominant negative effect. However, they found the monoallelic expression of Pit-1 gene in the unaffected father and grandmother by RT-PCR from lymphocyte RNA and suggested that the mutant allele is silent when it is transmitted from the mother. Another familial case was reported by de Zegher et al. (15). They described a mother-infant pair with GH, PRL and TSH deficiencies found to be heterozygous for this mutation. In this case, mutant allele seems not to be silent, although it is transmitted from the mother. Consequently, R271W possibly does not lead to GH, PRL and TSH deficiencies through a simple dominant negative effect or through a genomic imprinting phenomenon.

In the present study, we performed in vitro expression studies almost under the same experimental conditions as the previous report (9). However, surprisingly, we could not confirm the dominant negative effect of $\mathrm{R} 271 \mathrm{~W}$ on the wild type to activate the Pit-1 targeted genes. In addition, R $271 \mathrm{~W}$ showed activity similar to the wild type, at least under our experimental conditions. Taken together with the evidence that phenotypically normal cases have been reported with this mutation, our results deny the relationship between R271W and GH, PRL and TSH deficiencies.

\section{Acknowledgements}

We thank Miss Chika Ogata for excellent technical assistance. This work was supported in part by a Grant-in-Aid for Scientific Research from the Japanese Ministry of Education, Science, Sports and Culture.

\section{References}

1 Dolle P, Gastrillo JL, Theill LE, Deerinck T, Ellisman M \& Karin M. Expression of GHF-1 protein in mouse pituitaries correlates both temporally and spatially with the onset of growth hormone gene activity. Cell $1990 \mathbf{6 0} 809-820$.

2 Simmons DM, Voss JW, Ingraham HA, Holloway JM, Broide RS, Rosenfeld MG et al. Pituitary cell phenotypes involve cell-specific Pit-1 mRNA translation and synergistic interactions with other classes of transcription factors. Genes and Development 19994 $695-711$. 
3 Ryan AK \& Rosenfeld MG. POU domain family values: flexibility, partnerships and developmental codes. Genes and Development 199711 1207-1225.

4 Rhodes SJ, Chen R, DiMattia GE, Scully KM, Kalla KA, Lin S et al. A tissue-specific enhancer confers Pit-1-dependent morphogen inducibility and autoregulation on the Pit-1 gene. Genes and Development $19937913-932$.

5 Li S, Crenshaw EB III, Rawson EJ, Simmons DM, Swanson LW \& Rosenfeld MG. Dwarf locus mutants lacking three pituitary cell types result from mutations in the POU-domain gene Pit-1. Nature $1990347528-533$.

6 Lin C, Lin SC, Chang CP \& Rosenfeld MG. Pit-1-dependent expression of the receptor for growth hormone releasing factor mediates pituitary cell growth. Nature $1992 \mathbf{3 6 0} 765-768$.

7 Petersenn S, Rasche AC, Heyens M \& Schulte H. Structure and regulation of the human growth hormone-releasing hormone receptor gene. Molecular Endocrinology 199812 233-247.

8 Iguchi G, Okimura Y, Takahashi T, Mizuno I, Fumoto M, Takahashi Y et al. Cloning and characterization of the $5^{\prime}$-flanking region of the human growth hormone-releasing hormone receptor gene. Journal of Biological Chemistry $1999 \mathbf{2 7 4}$ 12108-12114.

9 Radovick S, Nations M, Du Y, Berg LA, Weintraub BD \& Wondisford FE. A mutation in the POU-homeodomain of Pit-1 responsible for combined pituitary hormone deficiency. Science $19922571115-1121$.

10 Ohta K, Nobukuni Y, Mitsubuchi H, Fujimoto S, Matsuo N, Inagaki $\mathrm{H}$ et al. Mutations in the PIT-1 gene in children with combined pituitary hormone deficiency. Biochemical and Biophysical Research Communications $1992189851-855$.

11 Okamoto N, Wada Y, Ida S, Koga R, Ozono K, Chiyo H et al. Monoallelic expression of normal mRNA in the PIT1 mutation heterozygotes with normal phenotype and biallelic expression in the abnormal phenotype. Human Molecular Genetics 19943 $1565-1568$.

12 Irie Y, Tatsumi K, Kusuda S, Kawasaki H, Boyages SC, Nose O et al. Screening for PIT1 abnormality by PCR direct sequencing method. Thyroid $19955207-211$.

13 Hasegawa Y, Kikuchi K, Ohie T \& Tatsumi K. A boy with PIT1 gene mutation. Clinical Pediatrics Endocrinology 19954210.

14 Tatsumi K \& Amino N. PIT1 abnormality. Growth Hormone and IGF Research $1999918-23$.

15 de Zegher F, Pernasetti F, Vanhole C, Devlieger H, Berghe GV \& Martial JA. The prenatal role of thyroid hormone evidenced by fetomaternal Pit-1 deficiency. Journal of Clinical Endocrinology and Metabolism $1995 \mathbf{8 0} 3127-3130$.

16 Cohen LE, Wondisford FE, Saivatoni A, Maghnie M, Brucker-Davis F, Weintraub BD et al. A hot spot in the Pit-1 gene responsible for combined pituitary hormone deficiency: clinical and molecular correlates. Journal of Clinical Endocrinology and Metabolism $1995 \mathbf{8 0} 679-684$.

17 Aarskog D, Eiken HG, Bjerknes G \& Myking OL. Pituitary dwarfism in the R271W Pit-1 gene mutation. European Journal of Pediatrics 1997156 829-834.

18 Holl RW, Pfaffle R, Kim C, Sorgo W, Teller WM \& Heimann G. Combined pituitary deficiencies of growth hormone, thyroid stimulating hormone and prolactin due to Pit-1 gene mutation: a case report. European Journal of Pediatrics 1997156 835-837.

19 Ward L, Chavez M, Huot C, Lecocq P, Collu R, Decarie JC et al. Severe congenital hypopituitarism with low prolactin levels and age-dependent anterior pituitary hypoplasia: a clue to a PIT-1 mutation. Journal of Pediatrics 1998132 1036-1038.

20 Cohen LE, Zanger K, Brue T, Wondisford FE \& Radovick S. Defective retinoic acid regulation of the Pit-1 gene enhancer: a novel mechanism of combined pituitary hormone deficiency. Molecular Endocrinology 199913 476-484.

21 Pernasetti F, Milner R, Al Ashwal A, Zegher F, Chavez VM, Muller M et al. Pro239Ser: a novel recessive mutation of the Pit-1 gene in seven Middle Eastern children with growth hormone, prolactin, and thyrotropin deficiency. Journal of Clinical Endocrinology and Metabolism 199883 2079-2083.

22 Pellegrini-Bouiller I, Belicar P, Barlier A, Gunz G, Charvet JP, Jaquet $\mathrm{P}$ et al. A new mutation of the gene encoding the transcription factor Pit-1 is responsible for combined pituitary hormone deficiency. Journal of Clinical Endocrinology and Metabolism 1996 $812790-2796$.

23 Brown MR, Parks JS, Adess ME, Rich BH, Rosenthal IM, Voss TC et al. Central hypothyroidism reveals compound heterozygous mutations in the Pit-1 gene. Hormone Research 199849 98-102.

24 Irie Y, Tatsumi K, Ogawa M, Kamijo T, Preeyasombat C, Suprasongsin C et al. A novel E250X mutation of the PIT1 gene in a patient with combined pituitary hormone deficiency. Endocrine Journal $199542351-354$.

25 Pfaffle RW, DiMattia GE, Parks JS, Brown MR, Wit JM, Jansen M et al. Mutation of the POU-specific domain of Pit-1 and hypopituitarism without pituitary hypoplasia. Science $1992 \mathbf{2 5 7}$ 1118-1121.

26 Cohen LE, Wondisford FE \& Radovick S. Role of Pit-1 in the gene expression of growth hormone, prolactin, and thyrotropin. Endocrinology and Metabolism Clinics of North America 199625 523-540.

27 Tatsumi K, Miyai K, Notomi T, Kaibe K, Amino N, Mizuno Y et al. Cretinism with combined hormone deficiency caused by a mutation in the PIT1 gene. Nature Genetics 19921 56-58.

28 Hendriks-Stegeman BI, Augustijn KD, Bakker B, Holthuizen P, Van Der Vliet PC \& Jansen M. Combined pituitary hormone deficiency caused by compound heterozygosity for two novel mutations in the POU domain of the PIT1/POUF1 gene. Journal of Clinical Endocrinology and Metabolism 2001 86 1545-1550.

29 Kishimoto M, Okimura Y, Yagita K, Iguchi G, Fumoto M, Iida K et al. Novel function of transactivation domain of a pituitary specific transcription factor Pit-1. Journal of Biological Chemistry $200227745141-45148$.

30 Gat-Yablonski G, Lazar G, Pertzelan A \& Phillip M. A novel mutation in PIT-1: phenotypic variability in familial combined pituitary hormone deficiencies. Journal of Pediatric Endocrinology and Metabolism 200215 325-330.

31 Blankenstein O, Muhlenberg R, Kim C, Wuller S, Pfaffle R \& Heimann G. A new C-terminal located mutation (V272ter) in the PIT-1 gene manifesting with severe congenital hypothyroidism. Possible functionality of the PIT-1 C-terminus. Hormone Research $20025681-86$.

32 Andersen B \& Rosenfeld MG. POU domain factors in the neuroendocrine system: lessons from developmental biology provide insights into disease. Endocrine Reviews 200122 2-35.

Received 26 September 2002

Accepted 21 February 2003 